\title{
A gyógyszer okozta állcsontnekrózis prognózisát befolyásoló faktorok
}

\author{
Szentpéteri Szófia dr. - Restár László dr. \\ Németh Zsolt dr. - Vaszilkó Mihály dr.
}

Semmelweis Egyetem, Fogorvostudományi Kar, Arc-, Állcsont-, Szájsebészeti és Fogászati Klinika, Budapest

Bevezetés: A gyógyszer okozta állcsontnekrózis (MRONJ) prognózisában szerepet játszó lehetséges rizikófaktorok - az egyes faktorok esetében kapott eltérő eredmények miatt - továbbra is kutatások tárgyát képezik.

Célkitüzés: Munkánk során a MRONJ prognózisában szerepet játszó lehetséges rizikófaktorokat vizsgáltuk.

Módszer: Kutatásunkba a Semmelweis Egyetem Fogorvostudományi Karának Arc-, Állcsont-, Szájsebészeti és Fogászati Klinikáján 2006 júniusa és 2013 novembere közötti időszakban MRONJ miatt sebészi terápiával kezelt pácienseket vontuk be, minden egyéb beválogatási kritérium nélkül. A megbetegedés prognózisát a stádiumjavulás, a gyógyulás és a relapsusráta alapján vizsgáltuk. Az utánkövetési idő minden beteg esetében minimum 5 év volt.

Statisztikai analizis: Eredményeink kiértékelését a Fisher-féle egzakt teszt, a Mann-Whitney-teszt, a Kruskal-Wallispróba és a khi-négyzet-teszt segítségével végeztük. Szignifikáns eredménynek fogadtuk el, ha a p<0,05 volt. A kiértékeléshez az SPSS Statistics 22.0 programot használtuk.

Eredmények: Az első találkozáskor rögzített stádium szignifikánsan rontotta a megbetegedés prognózisát $(\mathrm{p}=0,009)$. A diabetes mellitusban szenvedő betegek relapsusrátája a cukorbetegséggel nem rendelkező́khöz viszonyítva szignifikánsan magasabb $(\mathrm{p}=0,050)$. A relapsusráta tekintetében az ösztrogénellenes terápiában részesült betegek és a hormonkezelést nem kapott betegek közötti összefüggés szignifikáns ( $\mathrm{p}=0,036)$. A mandibulán kialakult nekrózisok prognózisa szignifikánsan rosszabb $(\mathrm{p}=0,003)$, mintha a maxillában alakultak volna ki. Vizsgálati eredményeink a nem, az életkor, a biszfoszfonát adagolási formája, a nekrózist megelőző invazív szájüregi beavatkozások, valamint a kemoterápiás és szteroidkezelés esetében nem mutattak statisztikailag igazolható összefüggést a megbetegedés prognózisával.

Következtetés: A kutatásunk során vizsgált tényezők közül a MRONJ prognózisát a diagnosztizáláskor észlelt stádium, az állcsont-lokalizáció, a kísérő betegségként fennálló diabetes mellitus, a biszfoszfonátterápia mellett alkalmazott ösztrogénellenes terápia befolyásolja.

Orv Hetil. 2020; 161(8): 283-289.

Kulcsszavak: gyógyszer okozta állcsontnekrózis, prognosztikai faktor, MRONJ, biszfoszfonát

\section{Prognostic factors of the medication-related osteonecrosis of the jaw}

Introduction: The potential risk factors of the medication-related osteonecrosis of the jaw remain the subject of research because of the different results of the studies.

Aim: In our study, we examined the potential prognostic factors of the medication-related osteonecrosis of the jaw. Method: Patients with medication-related osteonecrosis of the jaw presenting between June 2006 and November 2013 were included in this study. Prognosis was examined, based on stage improvement, healing and the rate of relapse. The minimum follow-up time was 5 years.

Statistical analysis: The results were evaluated by Fisher's exact test, Mann-Whitney test, Kruskal-Wallis probe and chi-square test. The outcomes were accepted as significant when the $p$ value was $<0.05$.

Results: The stage stated at the first check-up indicated poor prognosis $(\mathrm{p}=0.009)$. The relapse rate of patients with non-insulin-dependent diabetes mellitus was significantly higher than the relapse rate of those without diabetes mellitus $(\mathrm{p}=0.050)$. Regarding the relapse rate, the relationship between patients receiving anti-estrogen therapy and those without hormonal therapy was significant $(\mathrm{p}=0.036)$. The prognosis of mandibular necrosis was significantly worse $(\mathrm{p}=0.003)$ than the prognosis of maxillary necrosis. We did not find significant connection between prognosis and gender, age, administration route of bisphosphonate, invasive procedures preceding the necrosis, chemotherapeutic and steroid treatment. 
Conclusion: Of the factors studied here, the stage stated at the first check-up, the localization of the necrotic bone parts, diabetes mellitus and anti-estrogen therapy used simultaneously with the antiresorptive therapy affected the prognosis of the medication-related osteonecrosis of the jaw.

Keywords: medication-related osteonecrosis of the jaw, prognostic factor, MRONJ, bisphosphonate

Szentpéteri Sz, Restár L, Németh Zs, Vaszilkó M. [Prognostic factors of the medication-related osteonecrosis of the jaw]. Orv Hetil. 2020; 161(8): 283-289.

(Beérkezett: 2019. augusztus 24.; elfogadva: 2019. szeptember 21.)

\section{Rövidítések}

AAOMS $=($ American Association of Oral and Maxillofacial Surgeons) Amerikai Arc-, Állcsont- és Szájsebészeti Társaság; $\mathrm{HbA}_{1 \mathrm{c}}=$ hemoglobin- $\mathrm{A}_{1 \mathrm{c}} ; \mathrm{MRONJ}=$ (medication-related osteonecrosis of the jaw) gyógyszer okozta állcsontnekrózis; OP $=($ orthopantomogram $)$ panorámaröntgen-felvétel; RANKL $=$ (receptor activator of nuclear factor kappa-B ligand) a nukleáris faktor kappa-B receptoraktivátor ligandja

A gyógyszer okozta állcsontnekrózis (medication-related osteonecrosis of the jaw, MRONJ) 2003 óta ismert [1, 2], viszonylag új, esetenként igen súlyos megbetegedés.

A kórkép kialakulásában szerepet játszó lehetséges rizikófaktorokat számos kutatócsoport vizsgálta. Egyes tényezők - mint a nem, az életkor, az alapbetegség - szerepéről a MRONJ létrejöttében megoszlanak a vélemények [3-6]. Más tényező - mint a nekrózist megelőző invazív fogászati beavatkozás - a vizsgálatok legnagyobb részében pozitív korrelációt mutat a betegség jelentkezésével [7-9]. A biszfoszfonát adagolásának hossza, módja és az alkalmazott biszfoszfonátkészítmény típusa szintén korrelációt mutat a megbetegedés kialakulásával [1012]. Az alapbetegség kezelésében alkalmazott kemoterápia és antiösztrogén-kezelés szintén segíti a megbetegedés kifejlődését [13-16]. A szteroidok alkalmazása egyes kutatócsoportok szerint szerepet játszik a kórkép létrejöttében, míg mások ezt cáfolják [3, 13].

Vizsgálatunk során a kórkép kialakulásában szerepet játszó lehetséges rizikófaktorok prognózist befolyásoló hatását vizsgáltuk. Célunk olyan tényezők feltárása volt, melyek a megbetegedés kimenetelét befolyásolják, így meghatározhatják a választandó terápiás stratégiát.

\section{Módszer}

\section{Betegek}

Kutatásunkba a Semmelweis Egyetem Fogorvostudományi Karának Arc-, Állcsont-, Szájsebészeti és Fogászati Klinikáján 2006 júniusa és 2013 novembere közötti időszakban MRONJ-sal diagnosztizált és sebészi terápiával kezelt betegeket vontuk be, minden egyéb beválogatási kritérium nélkül.

A MRONJ diagnózisát az Amerikai Arc-, Állcsont- és Szájsebészeti Társaság (AAOMS) állásfoglalása alapján határoztuk meg az anamnézis, a klinikai vizsgálat és panorámaröntgen-felvétel (OP) tükrében [17]. A kórkép diagnosztikai kritériumait és stádiumbeosztását az 1. táblázat foglalja össze.

\section{Kezelési stratégia}

A kezelési stratégiát az AAOMS állásfoglalását követve a beteg szubjektív panaszaival összhangban - fájdalom, nervus alveolaris inferior érintettség - határoztuk meg, kivéve az 1 -es stádium esetén, amelynél a 4 hét sikertelen konzervatív kezelést követően mútétet végeztünk [17].

Antibiotikumkezelést minden esetben alkalmaztunk. Konzervatív terápia esetében maximum négyhetes anti-

1. táblázat | A gyógyszer okozta állcsontnekrózis diagnosztikai kritériumai és stádiumbeosztása

A gyógyszer okozta állcsontnekrózis diagnosztikai kritériumai az AAOMS 2014. évi ajánlása alapján

Jelenlegi vagy korábbi antireszorptív vagy antiangiogenikus gyógyszerekkel történő kezelés

Több mint 8 hete fennálló szabad csontfelszín vagy intraoralis / extraoralis fistulanyíláson át szondázható csontfelszín a maxillofacialis régióban

Nem történt besugárzás vagy nincs nyilvánvaló metasztatikus folyamat az állcsontok területén

A gyógyszer okozta állcsontnekrózis stádiumbesorolása az AAOMS 2014. évi ajánlása alapján

0. Nincs klinikai evidencia nekrotikus csont jelenlétére, de nem specifikus panaszok, klinikai tünetek és radiológiai elváltozások figyelhetók meg

1. Denudált csontfelszín vagy csontra vezető fistulanyílás figyelhető meg, de a beteg panaszmentes, infekcióra utaló jel nem látható

2. Denudált csontfelszín vagy csontra vezető fistulanyílás, melynek környezete fájdalmas és erythemás, pus ürülésével/a nélkül

3. Denudált csontfelszín vagy csontra vezető fistulanyílás fájdalommal és gyulladásos jelekkel, amire az alábbiak közül legalább egy igaz: a denudált, nekrotikus csontterület túlnyúlik az alveolaris csont régióján (azaz a mandibula alsó határa és ramusa; a felső állcsontnál a sinus maxillaris és a zygoma), ezzel patológiás fracturát vagy extraoralis fistulát vagy oroatralis fistulát vagy oronasalis fistulát vagy az állcsont alsó határáig nyúló csontlaesiót okozva

AAOMS = Amerikai Arc-, Állcsont- és Szájsebészeti Társaság 
biotikumkezelést folytattunk. Sebészi terápia esetében a sebészi beavatkozást megelőzően három nappal és a sebészi beavatkozást követően 10 napig alkalmaztunk antibiotikumterápiát. Primer antibiotikumként általában amoxicillin + klavulánsav készítményeket használtunk (amoxicillin + klavulánsav 875/125 mg, $2 \times 1$ ), de penicillinallergia esetén klindamicint (klindamicin $300 \mathrm{mg}$, $4 \times 1$ ) és doxiciklint (doxiciklin $100 \mathrm{mg}, 2 \times 1$ ) is adagoltunk. Amennyiben lehetséges volt, a pusból bakterológiai mintát vettünk, és antibiogram alapján célzott antibiotikumterápiát végeztünk.

A beteg beleegyezésével 2-es és 3-as stádiumban mindig sebészi terápiát alkalmaztunk. A beavatkozást a nekrózis méretétől és kiterjedésétől függően helyi érzéstelenítésben vagy intratrachealis narcosisban végeztük. A mütéti beavatkozás során minimálinvazív módon az öszszes lehetséges elhalt csontszövet eltávolítására, de maximális mennyiségű ép csontszövet megkímélésére törekedtünk. A mütéti területet 2\%-os Lidocain-adrenalinnal infiltráltuk. A nekrotikus területet minimálinvazív módon gerincéli metszésből mucoperiostealis lebeny képzésével tártuk fel. Sequester esetében eltávolítottuk a sequestert, a nekrotikus csontterületet sebészi fúró segítségével elvettük a vérző csontfelszínekig. Az éles csontszéleket ezt követően lekerekítettük. A mucoperiostealis lebenyt mobilizáltuk. A sebszéleket felfrissítettük, ezzel eltávolítva a gyulladásos nyálkahártyarész szélső területét. A sebet per primam egy rétegben vertikális matracöltésekkel zártuk. Betegeinknek a mütétet követő 1 hétben javasoltuk a mütéti terület jegelését, szájöblögető (klórhexidin, 0,2\%) használatát naponta minimum háromszor és a fokozott szájhigiénét.

Betegeink kontrollja 7-10 nappal a mütétet követően mindig megtörtént; javasoltuk az ismételt kontrollt 2 héten belül, majd 3 havonta, illetve panaszok esetén a beteg azonnali jelentkezését. A minimális utánkövetési idő 5 év volt.

\section{A prognózis vizsgálata}

A vizsgálatba csak operált betegeket vettünk be, a prognózist a gyógyulás, a relapsusráta és a stádiumváltozás alapján vizsgáltuk. Gyógyulásról beszélünk abban az esetben, ha a korábbi mütéti területen sem fizikális vizsgálattal, sem radiológiailag nem mutatható ki nekrózis a beavatkozást követően. Relapsusnak tekintettük, ha dokumentáltan legalább négy hét klinikai és radiológiai értelemben is gyógyult állapot után tért vissza a betegség, minden egyéb fogászati vagy szájsebészeti beavatkozás nélkül. A stádiumváltozást a diagnosztizáláskor rögzített stádiumhoz képest a beavatkozást követően négy héttel állapítottuk meg.

\section{Statisztikai elemzés}

Statisztikai számításaink során a kapott adatokat a prognózis függvényében elemeztük. Az elemzést Fisher-féle egzakt teszt, Mann-Whitney-teszt, Kruskal-Wallis-próba és khi-négyzet-teszt segítségével végeztük. Szignifikáns eredménynek fogadtuk el, ha a $\mathrm{p}<0,05$ volt. A kiértékeléshez az SPSS Statistics 22.0 programot (IBM Corporation, Armonk, NY, Amerikai Egyesült Államok) használtuk.

\section{Eredmények}

Munkánk során 106 beteg anamnesztikus és kezelési adatai kerültek feldolgozásra.

\section{Nem}

A vizsgált betegcsoportban 82 nő $(77,4 \%)$ és 24 férfi $(22,6 \%)$ volt. A MRONJ relapsusrátáját vizsgálva a nemek viszonyában nem kapunk szignifikáns eredményt ( $\mathrm{p}$ $=0,122)$, úgy, ahogyan a nemi megoszlás és a stádiumjavulás $(\mathrm{p}=0,852)$, valamint a gyógyulás $(\mathrm{p}=0,599)$ tekintetében sem.

\section{A diagnosztizáláskor rögzitett stádium}

Az első vizsgálatkor 1 -es stádiumban 22 fó (20,75\%), 2 -es stádiumban 62 páciens $(58,5 \%), 3$-asban pedig 22 beteg $(20,75 \%)$ volt. Az első találkozáskor rögzített stádium alapján a kezelési eredményesség sem a stádiumjavulás tekintetében $(\mathrm{p}=0,117)$, sem a gyógyulás tekintetében nem szignifikáns ( $\mathrm{p}=0,697)$ khi-négyzet-teszttel. Az első találkozáskor rögzített stádium és a relapsusráta alapján számított prognózis azonban szignifikáns ( $\mathrm{p}=$ 0,009), amit az 1. ábra szemléltet.

\section{A biszfoszfonátkészitmény adagolásának módja}

Vizsgáltuk az alkalmazott biszfoszfonát adagolási módjának prognózist befolyásoló hatását is. A vizsgálatunkba bevont összes betegünk biszfoszfonátterápiában részesült, RANKL-inhibitor betegeinknél nem került alkal-

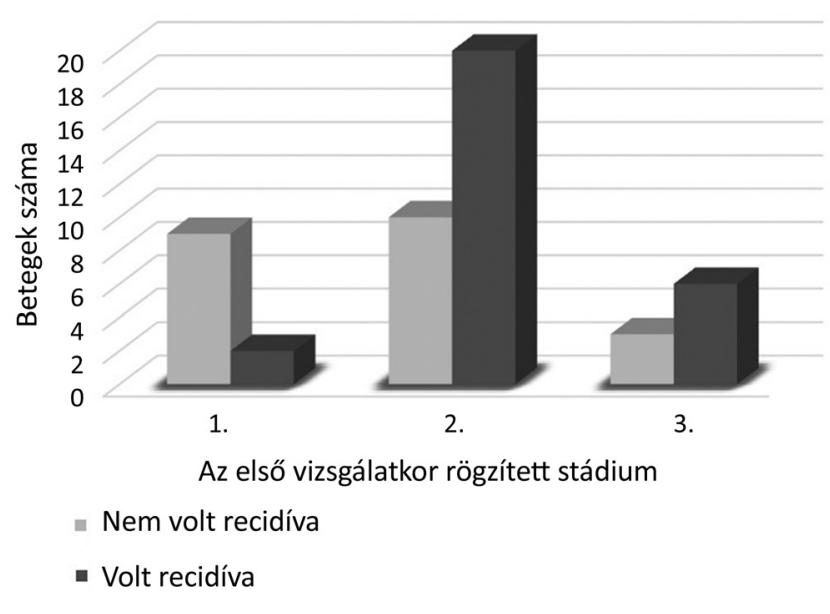

1. ábra $\quad$ Az első vizsgálatkor észlelt stádium és a prognózis összefüggése 
mazásra. Csak per os biszfoszfonátterápiában 31 betegünk $(30,1 \%)$ részesült. A többi beteg vagy csak parenteralisan kapta a biszfoszfonátot, vagy per os és intravénás alkalmazás is szerepelt az anamnézisükben. Ahol párhuzamosan más kiszerelési forma is szerepelt az anamnézisben, az intravénás formát vettük alapul. $\mathrm{Az}$ intravénás és per os kiszerelést kapó betegeket különválasztva sem a MRONJ relapsusrátájában $(\mathrm{p}=0,603)$, sem a gyógyulás tekintetében $(\mathrm{p}=0,430)$, sem a stádiumjavulás terén $(\mathrm{p}=0,419)$ nem kaptunk szignifikáns eredményt.

\section{Lokalizáció}

A nekrózisok a primer lokalizációjukat tekintve 28,8\%ban a maxillán, 65,4\%-ban a mandibulán és 5,8\%-ban mindkét állcsonton jelentkeztek. A maxillán kialakult nekrózisok a stádiumjavulást tekintve szignifikánsan jobban javultak kezelés hatására, mint a mandibulán megjelent állcsontelhalások $(\mathrm{p}=0,003)$. Az eredményt a 2 . ábra szemlélteti. A nekrózis lokalizációja az állcsontokat tekintve és a nekrózis relapsusainak viszonya nem mutat szignifikáns összefüggést $(\mathrm{p}=0,444)$. A nekrózis lokalizációja az állcsontokat tekintve a gyógyulással sem mutat összefüggést ( $p=0,383)$. A nekrózis lokalizációja a különböző kvadránsokban és a kezelés hatására bekövetkező stádiumjavulás sem szignifikáns ( $\mathrm{p}=0,241)$, úgy, ahogyan a kvadránsokban jegyzett lokalizáció és a gyógyulás $(\mathrm{p}=0,631)$ és betegség relapsusának létrejötte sem $(\mathrm{p}=0,185)$. A betegség lokalizációját vizsgáltuk a szextánsok tekintetében is. Nem találtunk szignifikanciát a szextánsok tekintetében sem a stádiumjavulás ( $\mathrm{p}=$ $0,366)$, sem a gyógyulás $(\mathrm{p}=0,398)$, sem a relapsusráta viszonylatában $(\mathrm{p}=0,879)$.

\section{Invazív beavatkozás}

Vizsgáltuk, hogy a nekrózis kialakulása előtt történt-e bármilyen orvosi beavatkozás. Fogászati beavatkozás vagy invazív esemény a MRONJ lokalizációjában - a kö-

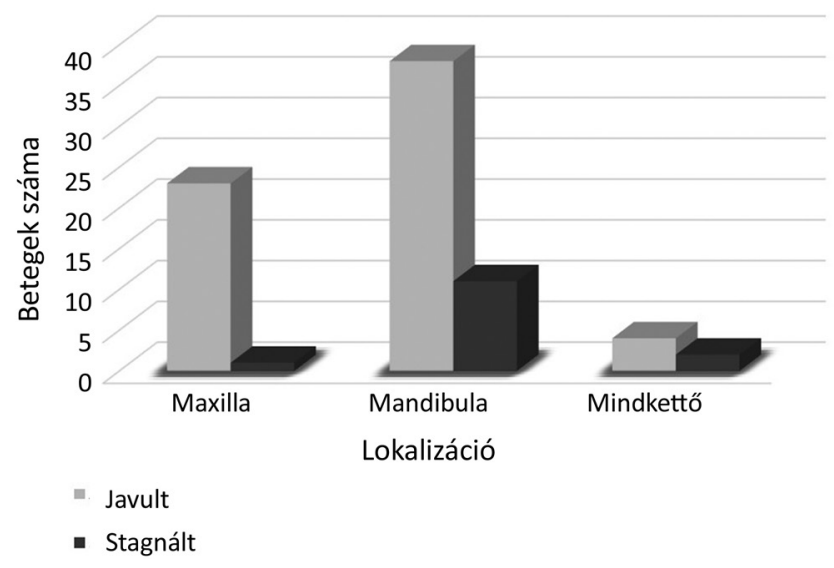

2. ábra |A nekrózis lokalizációja és a prognózis összefüggése zeli anamnézisben - 71 esetben történt $(67,6 \%)$. A fogászati beavatkozások sem a MRONJ relapsusrátájával ( $\mathrm{p}=$ $0,773)$, sem a gyógyulással $(\mathrm{p}=0,493)$, sem a stádium javulásával $(\mathrm{p}=0,264)$ nem mutattak szignifikáns összefüggést.

\section{Szteroidterápia}

Szteroid alkalmazása a korábbi terápiák során 17 esetben volt bizonyítható $(18,5 \%), 75$ beteg nem kapott szteroidot, 14 betegnél nem volt biztos adatunk a gyógyszeres terápiáról. Sem a kezelés során mutatott stádiumjavulás terén $(\mathrm{p}=0,875)$, sem a gyógyulást tekintve $(\mathrm{p}=0,169)$, sem a relapsusok előfordulási gyakoriságában $(\mathrm{p}=0,469)$ nem változtatott a prognózison az anamnézisben szereplő szteroidkezelés.

\section{Kemoterápia}

Kemoterápia az anamnézisben 77 esetben fordult elő (74\%). A megbetegedés prognózisa és az alkalmazott kemoterápiás kezelés között nem találtunk összefüggést sem a stádiumjavulást $(\mathrm{p}=0,707)$, sem a gyógyulást $(\mathrm{p}=$ $0,386)$, sem a MRONJ relapsusrátáját $(\mathrm{p}=0,469)$ tekintve.

\section{Diabetes mellitus}

25 betegról volt pozitív anamnézisünk a diabetes mellitus tekintetében. Ebből 5 betegnek volt magasabb éhgyomri vércukorértéke, mint $7 \mathrm{mmol} / \mathrm{l}$. Az 5 betegból 3 -nak volt relapsusa, 2-nek pedig nem. A beállított vércukorértékkel rendelkező többi cukorbetegnél 13 esetben találtunk relapsust, 7 esetben nem. Az emelkedett vércukorértékkel rendelkező csoport és a beállított vércukorértékkel rendelkező csoport relapsusainak aránya nem kiemelkedően tér el, statisztikai eltérés nincs. Tekintettel erre, a $\mathrm{HbA}_{1 c}$-értékek ismeretének hiányára, illetve a csoportok kis betegszámaira, egyben értékeljük a dia-

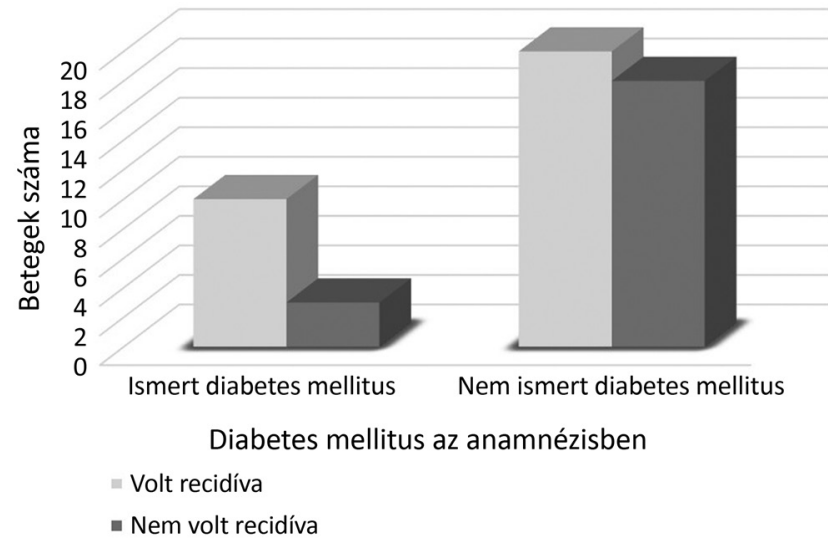

3. ábra $\quad$ Az anamnézisben szereplő diabetes mellitus és a prognózis öszszefüggése 


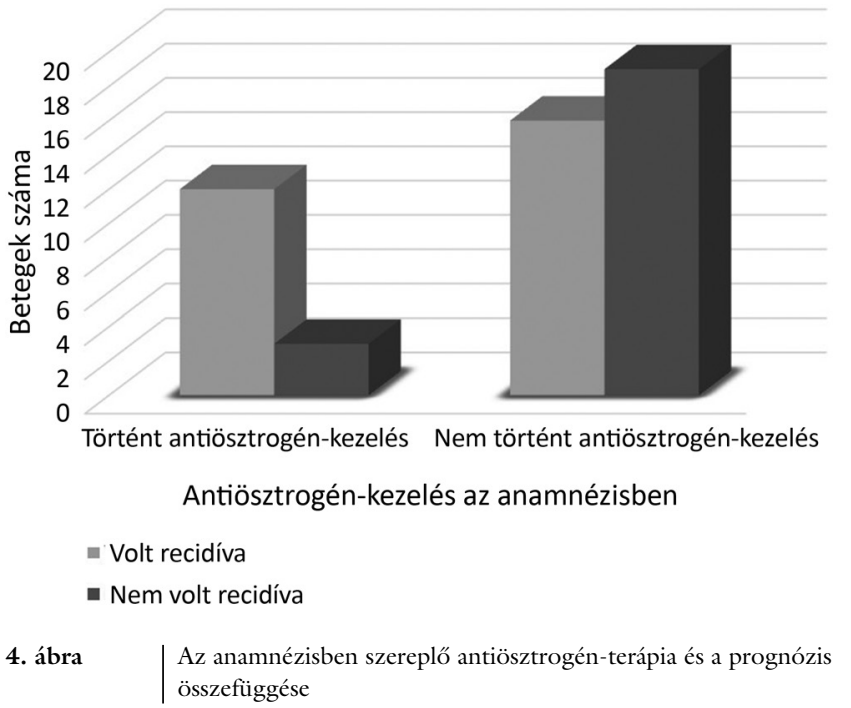

betesszel rendelkező betegeket, függetlenül az aktuálisan mért vércukorszinttől. A diabetes mellitusban szenvedő betegek és a cukorbetegséggel nem rendelkezők nekrózisrelapsusa Fisher-féle egzakt teszttel szignifikáns: $\mathrm{p}=0,050$. A kapott eredményt a 3. ábra szemlélteti. A diabetes mellitusnak a kezelés során mutatott stádiumjavulással nem szignifikáns az összefüggése $(\mathrm{p}=0,861)$, úgy, ahogy a gyógyulással sem $(\mathrm{p}=0,056)$.

\section{Ösztrogénellenes terápia}

50 mammatumoros betegből 40-rôl van biztos adatunk az antiösztrogén-terápia vonatkozásában, közülük 33-an $(82,25 \%)$ kaptak valamilyen ösztrogénellenes terápiát,

2. táblázat A vizsgált anamnesztikus és terápiás adatok és a prognózis összefüggése

\begin{tabular}{|c|c|c|c|c|}
\hline \multirow[t]{2}{*}{$\begin{array}{l}\text { A vizsgált anamneszti- } \\
\text { kus és terápiás adat }\end{array}$} & \multicolumn{3}{|c|}{$\begin{array}{c}\text { A vizsgált adat és a prognózis } \\
\text { korrelációja }\end{array}$} & \multirow[t]{2}{*}{$\begin{array}{l}\text { Korre- } \\
\text { láció }\end{array}$} \\
\hline & $\begin{array}{l}\text { Stádium- } \\
\text { javulás }\end{array}$ & Gyógyulás & $\begin{array}{l}\text { Relap- } \\
\text { susráta }\end{array}$ & \\
\hline Nem & $\mathrm{p}=0,852$ & $\mathrm{p}=0,599$ & $\mathrm{p}=0,122$ & Nem \\
\hline $\begin{array}{l}\text { Az első vizsgálatkor } \\
\text { rögzített stádium }\end{array}$ & $\mathrm{p}=0,117$ & $p=0,697$ & $p=0,009$ & Igen \\
\hline $\begin{array}{l}\text { A biszfoszfonát } \\
\text { adagolásának módja }\end{array}$ & $\mathrm{p}=0,419$ & $\mathrm{p}=0,430$ & $p=0,603$ & $\mathrm{Nem}$ \\
\hline \multicolumn{5}{|l|}{ Lokalizáció } \\
\hline Állcsont & $\mathrm{p}=0,003$ & $\mathrm{p}=0,383$ & $\mathrm{p}=0,444$ & Igen \\
\hline Kvadráns & $\mathrm{p}=0,241$ & $\mathrm{p}=0,631$ & $\mathrm{p}=0,185$ & $\mathrm{Nem}$ \\
\hline Szextáns & $\mathrm{p}=0,366$ & $p=0,398$ & $\mathrm{p}=0,879$ & $\mathrm{Nem}$ \\
\hline $\begin{array}{l}\text { Invazív beavatkozás az } \\
\text { adott területen }\end{array}$ & $p=0,264$ & $\mathrm{p}=0,493$ & $\mathrm{p}=0,773$ & $\mathrm{Nem}$ \\
\hline Kortikoszteroidterápia & $\mathrm{p}=0,875$ & $\mathrm{p}=0,169$ & $p=0,469$ & Nem \\
\hline Kemoterápia & $\mathrm{p}=0,707$ & $\mathrm{p}=0,386$ & $p=0,469$ & $\mathrm{Nem}$ \\
\hline Diabetes mellitus & $\mathrm{p}=0,861$ & $\mathrm{p}=0,056$ & $\mathrm{p}=0,050$ & Igen \\
\hline Antiösztrogén-terápia & $\mathrm{p}=0,247$ & $\mathrm{p}=0,331$ & $\mathrm{p}=0,036$ & Igen \\
\hline
\end{tabular}

7 -en pedig nem (17,5\%). Az összefüggés az ösztrogénellenes terápiában részesült betegek relapsusszáma és az antiösztrogén-kezelést nem kapott betegek MRONJ-kiújulása között szignifikáns a Fisher-féle egzakt teszttel $(\mathrm{p}=0,036)$. Eredményünket 4. ábra mutatja. Az ösztrogénellenes terápiában részesültek felvételkori átlagos stádiuma 2 , míg a hormonterápiában nem részesült betegek átlaga 1,85 volt; ha ugyanezt a kezelés során elért legmagasabb stádium tükrében vizsgáljuk, a számok: 2,4 és 2,32 . Az ösztrogén elleni hormonterápia és az eredményes kezelés egyik mérőszáma, a stádiumjavulás között nincs szignifikáns összefüggés eredményeinkben $(\mathrm{p}=0,247)$, úgy, ahogyan a gyógyulás tekintetében sem $(\mathrm{p}=0,331)$.

A vizsgálatunk során kapott eredményeket a 2. táblázat foglalja össze.

\section{Megbeszélés}

A nemnek a MRONJ kialakulását befolyásoló szerepéról az irodalomban nincs egységes álláspont: egyes szerzők a nem és a MRONJ szignifikáns összefüggésérôl számolnak be [4], míg mások nem találtak statisztikailag igazolható kapcsolatot [6]. Sok szerző számol be a nók magasabb érintettségéről a megbetegedés tekintetében [5-7], amihez a mi vizsgálatunk is csatlakozik. A nemi eltérés magyarázatát több szerző az emlőtumoros betegeknek a prosztatadaganatosokkal szembeni nagyobb számára, illetve a nők körében észlelhetô nagyobb osteoporosisprevelanciára vezetik vissza $[5,9]$. A megbetegedés prognózisában az eddigi vizsgálatok szerint a nemi hovatartozás nem játszik szerepet [18], 2 éves utánkövetéssel sem [19]. Kutatásunk során sem találtunk összefüggést a nem és a MRONJ prognózisa között.

Irodalmi adatok mutatják, hogy az oralis biszfoszfonátszedés jelentősen kisebb rizikóval jár, mint az intravénás kezelés $[9,10]$. A megbetegedés gyógyulását tekintve az irodalomban nincs egységes álláspont: egyes szerzők szerint sequestrectomia esetén oralis biszfoszfonát alkalmazásakor mind a mútét utáni javulás, mind a 6 hónappal a mútét után regisztrált gyógyulási eredmény jobb, mint intravénás biszfoszfonát alkalmazása esetén [19]. Más szerző́k eredményei a mi vizsgálati eredményeinkhez hasonlóan nem találtak összefüggést a biszfoszfonát adagolásának módja és a betegség kimenetele között [20, 21].

A lokalizációt tekintve a mandibula és a maxilla viszonyában észlelt arány több közleményben is kettő az egyhez $[3,8,11]$. Filleul több tanulmányt is elemző, nagyszámú esetet feldolgozó adatai szerint a mandibula 65\%-ban, a maxilla 27\%-ban, illetve mindkét állcsont $8 \%$ ban érintett [8]. A mi adataink is hasonló arányokat mutatnak. Kutatásunk szerint, más vizsgálatokkal ellentétben, a lokalizáció az állcsontok tekintetében szignifikánsan befolyásolja a MRONJ kimenetelét [18, 19].

$\mathrm{Az}$ irodalmi adatok alapján a betegek anamnézisében körülbelül 75\%-ban foghúzás szerepel a MRONJ kiala- 
kulását megelőzően $[3,8,9,22]$. Betegeink között fogászati beavatkozás vagy invazív esemény a MRONJ kialakulását megelőzően 67,8\%-ban fordult elő, ami egyezik a nemzetközi adatokkal. Egyes szerzők szerint a már kialakult nekrózis gyógyulási esélyét a nekrózis kialakulását megelőző rutin fogászati beavatkozás nem befolyásolja [18]. Kutatásunk során azt találtuk, hogy az invazív, állcsontot érintő beavatkozások a nekrózis progresszióját nem befolyásolják.

A szteroidterápia alkalmazásáról mint a megbetegedés kialakulásában szerepet játszó rizikófaktorról megoszlanak a vélemények. Marx a 2005-ös közleményében komoly rizikófaktornak véli [3], míg Lazarovici a 2009-es publikációja alapján nem tartja komoly kockázati tényezőnek [23]. A megbetegedés prognózisa szempontjából kutatásunk alapján a szteroidterápia nem befolyásolja sem a stádiumjavulást, sem a relapsusok előfordulási arányát.

Az összefüggést a kemoterápiás kezelés és a MRONJ kialakulása között számos kutatócsoport leírta [10, 1315]. Kutatásunk során nem találtunk összefüggést sem a stádiumjavulás, sem a relapsusok számának tekintetében a MRONJ prognózisa és kemoterápia alkalmazása között. Találunk közleményt, amely szerint a kemoterápia alkalmazása a MRONJ prognózisa szempontjából rizikófaktornak bizonyul [24]. Eltérő eredményeink oka a vizsgált betegcsoportokban a kemoterápiában részesült betegek arányának nagy eltérése és a kezelési stratégia különbsége lehet.

Az AAOMS-stádiumok tekintetében betegeink között kiemelkedő a 2-es stádiummal jelentkezők számaránya $(58,5 \%)$. Ez az eredmény azonban így is elmarad a más közleményekben található 65-66\%-tól $[5,8]$. A betegeinknél észlelt induló 20,75\%-os 1-es és 20,75\%-os 3-as stádium enyhén magasabb, mint a más elemzésben közölt adatok $[5,8]$. A megbetegedés diagnosztizálásakor rögzített állapot prognózist befolyásoló hatását az irodalomban többen vizsgálták, a mi vizsgálatunkkal ellentétben azonban nem állapítottak meg összefüggést a diagnosztizáláskor rögzített stádium és a kimenetel között [18, 22]. Ezen eltérés valószínúleg az eltérő kezelési stratégiákra vezethető vissza. Más és más klinikai stádium esetén döntenek a konzervatív és a sebészi terápia alkalmazása mellett.

Az irodalmi adatokat összevetve nincs egységes álláspont a diabetes mellitusnak mint rizikófaktornak a szerepéről. Számos közleményben olvasható, hogy az azonos életkori csoporttal összevetve a MRONJ-ban szenvedő betegek körében lényegesen magasabb a diabetes mellitus vagy a csökkent glükóztolerancia előfordulása [6, 25-27]. Lazarovici 2009. évi közleménye szerint azonban nem talált összefüggést a MRONJ és a diabetes mellitus között [23], míg más vizsgálatok a diabetes mellitust az állcsontnekrózis egyik szisztémás rizikótényezőjének tartják [28, 29]. Az általunk vizsgált betegek körében a hazai átlaghoz képest magasabb a diabetes mellitusban szenvedők aránya [30]. Ha különválasztjuk a jó cukorértékekkel rendelkező betegeket az emelkedett vércukorértékkel rendelkezőktől, nem kapunk eltérő eredményt, sőt az emelkedett vércukorértékkel rendelkezők relapsusrátája még kedvezőbb is. Így az általunk észlelt statisztikai összefüggésért nem az aktuálisan mért magasabb vércukorérték és annak a másodlagos fertőzésveszélyt növelő hatása tehető felelőssé. A diabetes mellitus feltehetően az általa létrehozott elváltozásokon keresztül - úgymint microvascularis ischaemia, endothelsejt-diszfunkció, csökkent osteoblast- és osteoclastfunkció, valamint csökkent remodelling - vezethet a rosszabb prognózishoz [31, 32].

Napjainkban az adjuváns endokrin terápia a hormonreceptor-pozitív emlőrákok kezelésének elterjedt módszere [33]. Vizsgálatunkban az antiösztrogén-terápiában részesültek aránya a tumoros megbetegedésben szenvedők között 82,25\% volt. Egyes közleményekben ez a szám eléri a 100\%-ot [9]. A MRONJ kialakulásában az antiösztrogén-terápia statisztikailag igazolhatóan szignifikáns rizikófaktorként ismert, ami ebben a vizsgálatban a magasabb esetszámnál is igazolódott [16]. Jelen vizsgálatunkban a hormondeprivatiós kezelésben nem részesülő és az antiösztrogén hatású készítményekkel kezelt emlőtumoros betegek relapsusrátáját hasonlítottuk öszsze. A MRONJ relapsusainak számát illetően szignifikáns eredményt kaptunk. A károsító ágens a csontban reaktív folyamatot indukál, melynek meghatározó tényezője a csont bontó-építő mechanizmusa. Ez a reaktív folyamat a gyógyulást segíti elő. Az ösztrogénhiányos állapotban az osteoblastok proliferációja csökken, apoptózisa fokozódik, míg az osteoclastok száma, életideje és aktivitása növekszik [34]. A biszfoszfonáttal kezelt és ösztrogénhiányos állapotban így mind az osteoclastok, mind az osteoblastok múködése fékeződik, a remodelling két irányból is csökken. Feltételezhető tehát, hogy ezen mechanizmusokon keresztül az ösztrogénhiányos állapotban a csontok hajlamosabbak lesznek a károsító ágensek hatására bekövetkező elhalásra.

\section{Következtetés}

Munkánk eredményeként megállapíthatjuk, hogy a kialakult MRONJ prognózisát a nekrózisnak az észleléskor rögzített stádiuma, a diabetes mellitus egyidejü fennállása, a nekrózis lokalizációja és az ösztrogénellenes kezelés befolyásolja szignifikánsan.

Eddigi vizsgálati eredményeink a nem, az életkor, a biszfoszfonát adagolási formája, a biszfoszfonátkezelés időtartama esetében nem mutattak statisztikailag igazolható összefüggést a MRONJ prognózisával. A MRONJ kialakulását megelőzően történt invazív szájüregi beavatkozás, kemoterápiás és szteroidkezelés sem befolyásolja a megbetegedés kimenetelét. 
Anyagi támogatás: A közlemény megírása és a hozzá kapcsolódó kutatómunka anyagi támogatásban nem részesült.

Szerzői munkamegosztás: Sz. Sz.: A betegek kezelése, adatgyüjtés, az adatok összesítése és feldolgozása, a közlemény szövegének megírása, az ábrák és a táblázatok elkészítése. R. L.: Statisztikai elemzés. N. Zs.: A betegek kezelése, a közlemény szövegének megírása. V. M.: A betegek kezelése, adatok gyưjtése, a közlemény szövegének megírása, az ábrák készítése és javítása. A cikk végleges változatát valamennyi szerző elolvasta és jóváhagyta.

Érdekeltségek: A szerzőknek nincsenek érdekeltségeik.

\section{Irodalom}

[1] Wang J, Goodger NM, Pogrel MA. Osteonecrosis of the jaws associated with cancer chemotherapy. J Oral Maxillofac Surg. 2003; 61: 1104-1107.

[2] Marx RE. Pamidronate (Aredia) and zoledronate (Zometa) in duced avascular necrosis of the jaws: a growing epidemic. J Oral Maxillofac Surg. 2003; 61: 1115-1117.

[3] Marx RE, Sawatari Y, Fortin M, et al. Bisphosphonate-induced exposed bone (osteonecrosis/osteopetrosis) of the jaws: risk factors, recognition, prevention, and treatment. J Oral Maxillofac Surg. 2005; 63: 1567-1575

[4] Park W, Kim NK, Kim MY, et al. Osteonecrosis of the jaw in duced by oral administration of bisphosphonates in Asian population: five cases. Osteoporos Int. 2010; 21: 527-533.

[5] Otto S, Schreyer C, Hafner S, et al. Bisphosphonate-related osteonecrosis of the jaws - characteristics, risk factors, clinical features, localization and impact on oncological treatment. J Craniomaxillofac Surg. 2012; 40: 303-309.

[6] Hoff AO, Toth BB, Altundag K, et al. Osteonecrosis of the jaw in patients receiving intravenous bisphosphonate therapy. J Clin Oncol. 2006; 24(18_Suppl): 8528 .

[7] Ruggiero SL, Gralow J, Marx RE, et al. Practical guidelines for the prevention, diagnosis and treatment of osteonecrosis of the jaw in patients with cancer. J Oncol Pract. 2006; 2: 7-14.

[8] Filleul O, Crompot E, Saussez S. Bisphosphonate-induced osteonecrosis of the jaw: a review of 2,400 patient cases. J Cancer Res Clin Oncol. 2010; 136: 1117-1124.

[9] Hoff AO, Toth BB, Altundag K, et al. Frequency and risk factors associated with osteonecrosis of the jaw in cancer patients treated with intravenous bisphosphonates. J Bone Miner Res. 2008; 23 : 826-836

[10] Ruggiero SL, Dodson TB, Assael LA, et al. American Association of Oral and Maxillofacial Surgeons position paper on bisphosphonate-related osteonecrosis of the jaws - 2009 update. J Oral Maxillofac Surg. 2009; 67(5 Suppl): 2-12.

[11] Woo SB, Hellstein JW, Kalmar JR. Bisphosphonates and osteonecrosis of the jaws. Ann Intern Med. 2006; 144: 753-761.

[12] Dannemann C, Gratz KW, Riener MO, et al. Jaw osteonecrosis related to bisphosphonate therapy: a severe secondary disorder. Bone 2007; 40: 828-834.

[13] Hohnecker JA. Novartis 'Dear Doctor' precautions added to the label of Aredia and Zometa, September 24, 2004. Available from: http://www.fda.gov [accessed: September 20, 2019].

[14] Migliorati CA, Siegel MA, Elting LS. Bisphosphonate-associated osteonecrosis: a long-term complication of bisphosphonate treatment. Lancet Oncol. 2006; 7: 508-514.

[15] Hoff AO, Toth B, Hu M, et al. Epidemiology and risk factors for osteonecrosis of the jaw in cancer patients. Ann N Y Acad Sci. 2011; 1218: 47-54

[16] Vaszilkó M, Kovács E, Restár L, et al. Potential significance of antiestrogen therapy in the development of bisphosphonate re- lated osteonecrosis of the jaw. J Craniomaxillofac Surg. 2014; 42: 1932-1936.

[17] Advisory Task Force on Bisphosphonate-Related Ostenonecrosis of the Jaws, American Association of Oral and Maxillofacial Surgeons. American Association of Oral and Maxillofacial Surgeons position paper on bisphophonate-related osteonecrosis of the jaws. J Oral Maxillofac Surg. 2007; 65: 369-376.

[18] Wutzl A, Pohl S, Sulzbacher I, et al. Factors influencing surgical treatment of bisphosphonate-related osteonecrosis of the jaws. Head Neck 2012; 34: 194-200.

[19] Scoletta M, Arduino PG, Dalmasso P, et al. Treatment outcomes in patients with bisphosphonate-related osteonecrosis of the jaws: a prospective study. Oral Surg Oral Med Oral Pathol Oral Radiol Endod. 2010; 110: 46-53.

[20] Shintani T, Hayashido Y, Mukasa H, et al. Comparison of the prognosis of bisphosphonate-related osteonecrosis of the jaw caused by oral and intravenous bisphosphonates. Int J Oral Maxillofac Surg. 2015; 44: 840-844.

[21] Fukushima Y, Enoki Y, Nakaoka C, et al. Usability of surgical treatment in cases of bisphosphonate-related osteonecrosis of the jaw stage 2 with sequestrum. Ann Maxillofac Surg. 2015; 5: 67-70.

[22] Mücke T, Koschinski J, Deppe H, et al. Outcome of treatment and parameters influencing recurrence in patients with bisphosphonate-related osteonecrosis of the jaws. J Cancer Res Clin Oncol. 2011; 137: 907-913.

[23] Lazarovici TS, Yahalom R, Taicher S, et al. Bisphosphonate-related osteonecrosis of the jaws: a single-center study of $101 \mathrm{pa}$ tients. J Oral Maxillofac Surg. 2009; 67: 850-855.

[24] Yoshiga D, Nakamichi I, Yamashita Y, et al. Prognosis factors in the treatment of bisphosphonate-related osteonecrosis of the jaw - prognostic factors in the treatment of BRONJ. J Clin Exp Dent. 2014; 6: e22-e28.

[25] Khan AA, Morrison A, Hanley DA, et al. Diagnosis and management of osteonecrosis of the jaw: a systematic review and inter national consensus. J Bone Miner Res. 2015; 30: 3-23.

[26] Wessel JH, Dodson TB, Zavras AI. Zoledronate, smoking, and obesity are strong risk factors for osteonecrosis of the jaw: a casecontrol study. J Oral Maxillofac Surg. 2008; 66: 625-631.

[27] Favus MJ. Diabetes and the risk of osteonecrosis of the jaw. J Clin Endocrinol Metab. 2007; 92: 817-818.

[28] Soós B, Vajta L, Szalma J. Sunitinib and zoledronic acid induced osteonecrosis of the jaw. Case report. [Sunitinib és zoledronsav által indukált állcsont-osteonecrosis.] Orv Hetil. 2015; 156: 1865-1870. [Hungarian]

[29] Zurányi A, Vasziné Szabó E, Tóth Zs. Risk assessment of medication-related osteonecrosis of the jaw in general dental practice. [A gyógyszer által indukált állcsontnecrosis-kockázat mértékének meghatározása az általános fogorvosi gyakorlatban.] Orv Hetil. 2019; 160: 243-251. [Hungarian]

[30] Adeghate E, Schattner P, Péter A, et al. Diabetes mellitus and its complications in a Hungarian population. Arch Physiol Biochem. 2001; 109: 281-291.

[31] Peer A, Khamaisi M. Diabetes as a risk factor for medication-related osteonecrosis of the jaw. J Dent Res. 2015; 94: 252-260.

[32] Lakatos P. Pharmacologic treatment of osteoporosis - 2011 [Az osteoporosis gyógyszeres kezelése - 2011.] Orv Hetil. 2011; 152: 1320-1326. [Hungarian]

[33] Janovszky Á, Vereb T, Szabó A, et al. Current approaches for early detection and treatment of medication-related osteonecrosis of jaw. [Aktuális trendek a gyógyszer indukálta állcsontnecrosis korai felismerése és kezelési stratégiája terén.] Orv Hetil. 2014; 155: 1960-1966. [Hungarian]

[34] Syed F, Khosla S. Mechanisms of sex steroid effects on bone. Biochem Biophys Res Commun. 2005; 328: 688-696.

(Szentpéteri Szófia dr., Veresegyház, Fagyöngy u. 24., 2112 e-mail: szentpeteriszofia@gmail.com)

A cikk a Creative Commons Attribution 4.0 International License (https://creativecommons.org/licenses/by/4.0/) feltételei szerint publikált Open Access közlemény. (SID_1) 